\title{
DPLAfest 2015
}

\author{
日 程 2015 年4月17日(金) 18日(土) \\ 場 所 米国 インディアナポリス \\ 主 催 DPLA (Digital Public Library of America: DPLA)
}

情報管理. 2015, vol. 58, no. 4, p. 313-318. doi: http://dx.doi.org/10.1241/johokanri.58.313

\section{1.はじめに}

アーカイブのネットワークとしては，欧州の Europeanaと米国デジタル公共図書館（Digital Public Library of America：DPLA，以下，DPLA）が有名で ある11。このDPLAの年次大会にあたるDPLAfest 2015 が，2015年4月17日，18日に，インディアナ州の州 都インディアナポリスで開かれた注1)。この会議に参 加したので報告する。

\section{DPLAとは}

DPLAは，2013年4月18日に公開された米国各地 に存在する図書館ア一カイブの統合利用システムで ある（図1) 注2)。これは，すでに実績のある欧州の Europeana (http://www.europeana.eu/) をモデル としている2。これまで個別に散らばっていた図書 館ア一カイブを，一度に検索・閲覧できるようにし， さらには高度利用も可能にしようとする試みである。

DPLAの概念図は図2のようなものである注3)。

これによれば，DPLAはハブ（Hub）と呼ばれる州 ごとの図書館システム（A State Library System）や， 全米規模のアーカイブ（Aggregated Collection）か らメタデータを収集し $(\mathrm{OAI} / \mathrm{PMH})$ ，直接検索やユー ザーアプリケーションで検索できるようにし，その 結果，もとのコレクションを閲覧・利用できる仕組 みである。現在，図書館システムはサービス・ハブ， 全米規模のアーカイブはコンテンツ・ハブと呼ばれ る。対象となるデータは，写真，手稿，書籍，新聞， 聞き取り（oral history）その他の音声ファイル，ス トリーム・ビデオなどである。

当初（2012年10月）予定していたサービス・ハブと，

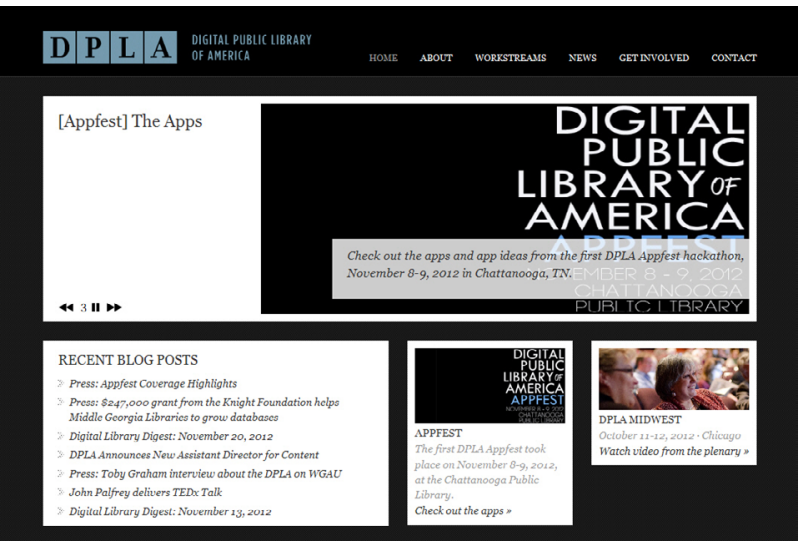

図1＼cjkstart米国デジタル公共図書館のWebサイト注2)

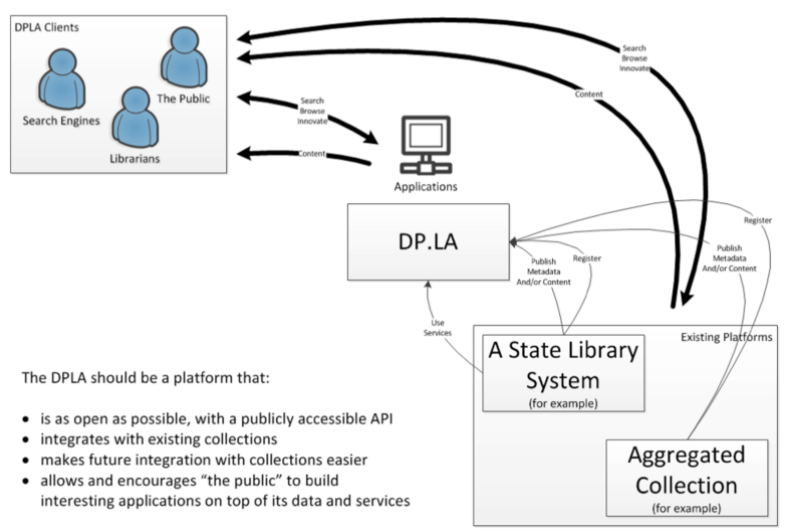

※詳細については注 3）の 4 ページ目を参照。

図2 DPLAの構造

2015年4月時点でのサービス・ハブ，コンテンツ・ハ ブは表1のとおりである注4)。

サービス・ハブの多くは州単位のアーカイブで， その州のさまざまなアーカイブを統合して提供す る。たとえば， North Carolina Digital Heritage Center には155館のパートナーがいる。コンテンツ・ハブは 博物館，美術館，国立公文書館などで，自分のデー タのみを提供するハブである。

DPLAのコンテンツ数は開設時240万件であったが， 
表1ＤPLAのサービス・ハブとコンテンツ・ハブ注4)

\begin{tabular}{|c|c|c|}
\hline & サービス・ハブ & コンテンツ・ハブ \\
\hline \multirow{8}{*}{$\begin{array}{l}2012 \text { 年 } 10 \\
\text { 月に予定さ } \\
\text { れていた八 } \\
\text { ブ }\end{array}$} & Mountain West Digital Library (Utah, & \\
\hline & Nevada and Arizona) & \\
\hline & Massachusetts Digital Commonwealth & \\
\hline & Digital Library of Georgia & \\
\hline & Kentucky Digital Library & \\
\hline & Minnesota Digital Library & \\
\hline & South Carolina Digital Library & \\
\hline & $\begin{array}{l}\text { Oregon Digital Library （現在は加わって } \\
\text { いない） }\end{array}$ & \\
\hline \multirow{16}{*}{$\begin{array}{l}2015 \text { 年 } 4 \\
\text { 月段階で加 } \\
\text { わっている } \\
\text { ハブ }\end{array}$} & Caribbean Service Hub & ARTstor \\
\hline & Connecticut Digital Archive & Biodiversity Heritage Library \\
\hline & Empire State Digital Network (NY) & California Digital Library \\
\hline & Indiana Memory & David Rumsey Map Collection \\
\hline & Maine Service Hub & The J. Paul Getty Trust \\
\hline & Maryland Service Hub & The U.S. Government Publishing Office \\
\hline & Missouri Hub & The Harvard Library \\
\hline & $\begin{array}{l}\text { Montana Memory Project （Mountain } \\
\text { West Digital Library を経由） }\end{array}$ & HathiTrust Digital Library \\
\hline & North Carolina Digital Heritage Center & Internet Archive \\
\hline & The Portal to Texas History & $\begin{array}{l}\text { National Archives and Records } \\
\text { Administration }\end{array}$ \\
\hline & Tennessee Service Hub & The New York Public Library \\
\hline & & The Smithsonian Institution \\
\hline & & The University of Florida \\
\hline & & $\begin{array}{l}\text { The University of Illinois at } \\
\text { Urbana-Champaign }\end{array}$ \\
\hline & & $\begin{array}{l}\text { University of Southern California } \\
\text { Libraries }\end{array}$ \\
\hline & & The University of Virginia \\
\hline
\end{tabular}

丸2年経って1,600機関からの995万9,000件に成長し た。会議中に2周年記念のセッションがあったが，そ こで追加の登載があり，ちょうど1,000万件を突破し たとの発表があった。

2年前にはサービス・ハブの数は5か所であったが， 今は17か所となった。しかし，まだ全米を力バーして いるわけではないので，継続的な努力が必要である。

コンテンツの出所としては公共図書館が $24 \%$ ，大

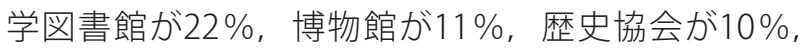
文書館が $6 \%$ となっている (図3 $)^{3)}$ 。最近の特徵とし ては，オーディオ・ビジュアルのアーカイブが増え たことがある。

事務局長のDan Cohenの発表によれば注5)，最近の 事業の拡大としては，HathiTrust注6) との協力により， 電子書籍の活用を進め始めていること，Learning Registry，教育テレビネットワークのPBS (Public
Broadcasting Service)， LearningMediaとの協力によ り，教育現場での活用に力を入れていること，など である。

\section{3. 会議の性格}

DPLAは全米各地の図書館や博物館，その他のアー カイブ機関の共同プロジェクトである。その推進力 は，(1) 理事会や事務局を支えるリーダーとサポー ター，(2) サービス・ハブである州単位のアーカイブ やコンテンツ・ハブ機関およびコンテンツ作成機関， (3) コア・システムの開発を支える技術者とAPIを利 用するハッカー，(4) 図書館員と利用者の4者から成つ ていると思われる。したがって今回の会議も次のよ うにそれら4者の二ーズに応えるものとなっている。

（1）DPLAの発展のための戦略的な活動

（2）ハブやコンテンツ作成機関の経験交流と提案 
（3）技術者のためのハッカソン

（4）図書館員と利用者のためのセッション
のとおりである。

以下，主なセッションの内容について報告するが，注 記のローマ数字は表2のセッション・テーマに対応する。

それぞれのカテゴリーのセッション・テーマは表2

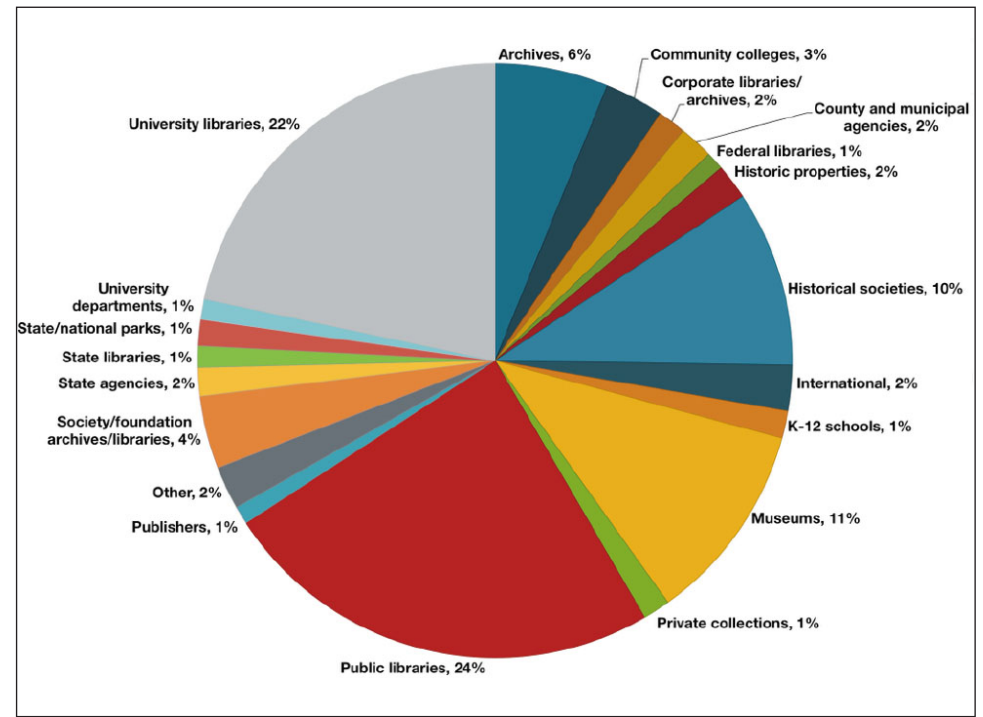

※詳細については，参考文献3）の「Copy of BecomingAHub-DPLAfest」を参照。

図3ＤPLAのコンテンツの出所

表2ＤPLAfest 2015のセッション・テーマー覧

\begin{tabular}{|c|c|c|}
\hline カテゴリー & \multicolumn{2}{|r|}{ セッション・テーマ } \\
\hline \multirow[t]{3}{*}{ 戦略的活動 } & 教育 & $\begin{array}{l}\text { DPLA 教育活用計画 （i） } \\
\text { K-12 学校での教育資源 （ii） } \\
\text { DPLA の K-12 教育への活用（iii） } \\
\text { DPLA の大学・カレッジでの活用（iv） }\end{array}$ \\
\hline & 提携 & $\begin{array}{l}\text { ウィキペディアで誰でも編集できる資源の探索（v） } \\
\text { ユーロピアーナにおけるテーマ別ユーザ開拓（vi） }\end{array}$ \\
\hline & 著作権 & $\begin{array}{l}\text { 著作権の障害克服 （vii） } \\
\text { 孤児著作物対策の実施例（viii） } \\
\text { 国際権利処理ワーキング・グループの報告（ix） }\end{array}$ \\
\hline $\begin{array}{l}\text { ハブ・コンテン } \\
\text { ツ機関 }\end{array}$ & $\begin{array}{l}\text { DPLA, } \\
\text { DPLA, } \\
\text { デジタル } \\
\text { メタデー } \\
\text { 大規模ラ } \\
\text { 小規模㭃 } \\
\text { リンク } \\
\text { 新聞と I } \\
\text { インディ } \\
\text { DPLA 篔 }\end{array}$ & 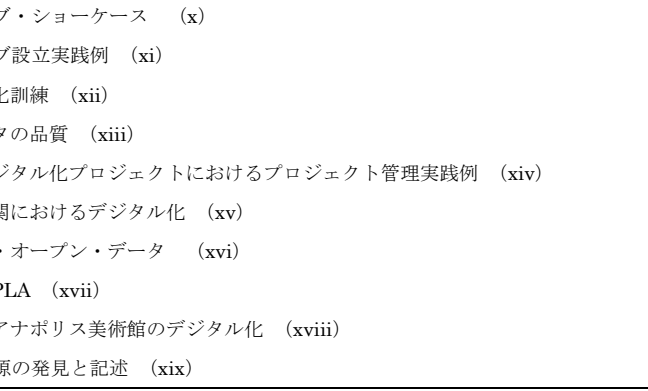 \\
\hline 技術者 & $\begin{array}{l}\text { DPLA P } \\
\text { ハッカン }\end{array}$ & $\begin{array}{l}\text { 発者ショーケース } \quad(\mathrm{xx}) \\
(1-3) \quad(\mathrm{xxi})\end{array}$ \\
\hline $\begin{array}{l}\text { 図書館員と利用 } \\
\text { 者 }\end{array}$ & $\begin{array}{l}\text { 電子書篓 } \\
\text { 電子書箖 } \\
\text { 研究図青 } \\
\text { インディ } \\
\text { DPLA } \\
\text { デジタル }\end{array}$ & 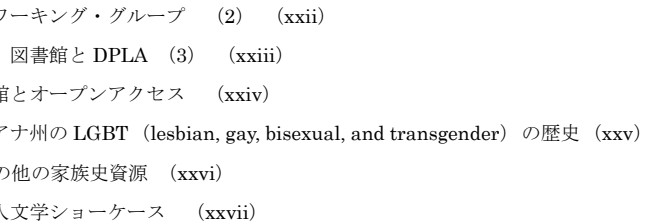 \\
\hline
\end{tabular}

※全体会議を除く，アラビア数字は複数セッションの件数，ローマ数字は本文中の引用。 
3.1 戦略的活動に関するセッション

(1) 教育分野での活用

DPLAでは教育機関での利用に力を入れている。 DPLAではWhiting Foundationの助成により，DPLAを K-12（幼稚園児から12歳まで）教育現場に活用する 研究を行った (i)。その成果は報告書として公開され ている4）。結論としては，DPLAのような歴史文化資 源を有効に活用するためには，特定の目的に特化し たコンテンツのキュレーションとアウトリーチ活動 が重要である。つまり，学校の利用者が的確なコン テンツに迅速にアクセスできること，またそのコン テンツが文化的歴史的文脈にきちんとはまっている ことである。今後教育関係機関と協力して応用を進 めていくことが重要であるとしている。

実践的には，DPLAを「驚きと発見の場」として利 用したり，「テーマを設定した学習」，「生徒の自主研 究」などに活用したりできるとする報告がある（iii）。

(2) Wikipediaとの提携

一般にアーカイブのコンテンツは，Wikipediaで引 用されると劇的にアクセス数が増加する。Wikipedia としても，出典としてオリジナルのコンテンツへの リンクが増えることは品質向上のため好ましい $(\mathrm{v})$ 。 WikipeDPLAはGoogle Chromeのプラグインである が，これをインストールするとWikipediaの記事に DPLAへのリンクが表示される。たとえば,「Sankeien， Yokohama」をクリックすると，DPLAにあるコンテ ンツにリンクする（図4）。

\section{（3）著作権について}

デジタル・アーカイブを構築する際に，著作権は 大きな問題となる。この点はDPLAにとっても同じで ある。こうしたアーカイブ機関のために，「図書館， 文書館，その他のアーカイブ機関が孤児著作物を含 むコレクションを構築する際のフェア・ユースの利 用実施基準」注7) が2014年12月に作成された。DPLA もこれを適用する (viii)。

図書館，公文書館，その他の歴史資料機関が孤児 著作物を含むコレクションのデジタル化を行う場合，

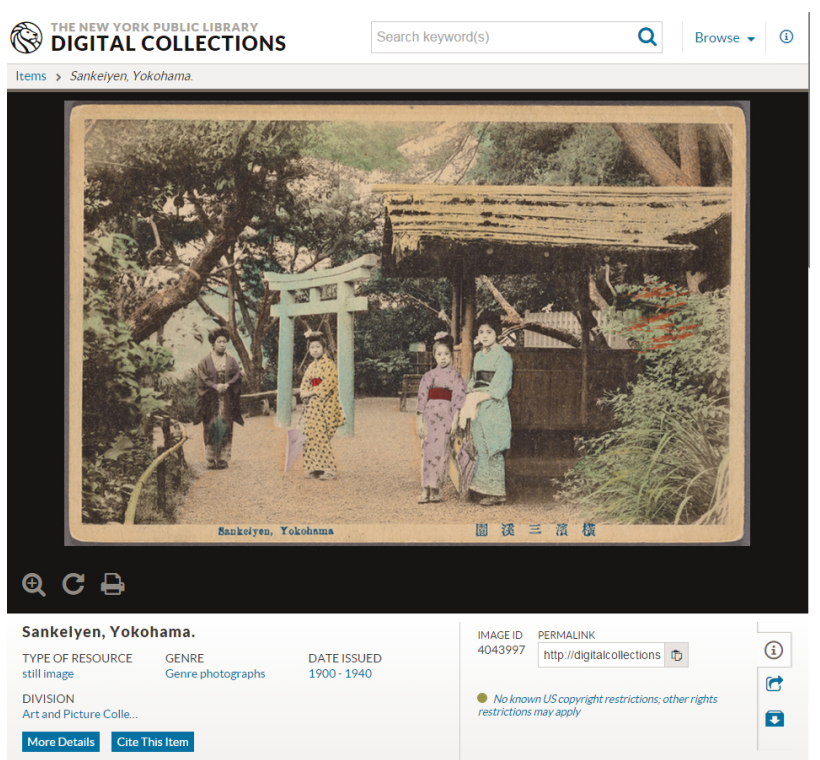

図4 WikipeDPLAからリンクした横浜三溪園の絵葉書写真

フェア・ユースを利用することにより，かなりの著 作権問題を解決できる。まず，これらアーカイブ機 関においては，資料のデジタル保存は孤児著作物を 含めフェア・ユースによって許されていると考えて いる。次に公開にあたっては，一定の手順が必要な ものの，これらの機関では，孤児著作物や著作権の あるコンテンツを含むコレクションのオンライン公 衆アクセスが原則としてフェア・ユースで許されて いると考えている。

また，なるべくコンテンツはCC-BYのような広範な 利用を認めるアクセスが好ましいが，現実にはコン テンツによっては複雑な権利記述がある。Europeana はこうした権利の種類を簡略化しており，DPLAも Europeanaと協力して権利記述の標準化に取り組んで いる (ix)。

3.2 ハブやコンテンツ作成機関に関するセッション （1）実施例

この関係のセッションではさまざまな発表があっ た。ハブの実践例については (xi)，スライド [Hubs Showcase Slides］を参照していただきたい注8)。

興味深い例としては，5,000万ページの新聞記事 の電子化を行ったNorth Carolina Newspapersや，地 
理メタデータの付与基準を作成したMountain West Digital Libraryがあった。

\section{（2）その他}

これからハブとして参加しようとする機関のため のセッション $(x i)$ ，職員の訓練（xii)，デジタル化の 実際（xv, xviii)，メタデータの品質（xiii），リンクト・ オープン・データ（xvi）などさまざまなセッション が行われた。

\section{3 技術者のためのセッション}

DPLAでもEuropeanaでも，設計の当初からAPIを各 方面の技術者に活用してもらうことにより，多角的 な利用を発展させるという戦略をとっている。した がって「ハッカソン」と呼ばれる技術者（ハッカー） の経験交流会は会議の重要な部分で，今回は1日半の 会議日程をフルに使って行われた（xx, xxi）。DPLAの APIはEuropeanaを参考にしており，「AND，OR，ワイ ルドカード $\left(^{*}\right)$ ，フィールド指定，年代指定，地理指定」 もできる。DPLAのApp Libraryがある（http://dp.la/ apps)。

\section{4 図書館員・利用者のためのセッション}

\section{(1) 電子書籍}

電子書籍は今回の会議の大きなトピックで，合計 5回のセッションが行われた。HathiTrustやInternet ArchiveのDPLA参加により，多量の電子書籍が利用可 能になっている。こうした電子書籍リソースを図書 館でどのように活用するかが討論された（xxii, xxiii）。

(2) デジタル人文学ショーケース

ここでは主としてHathiTrustのコンテンツを活用 してどんな研究ができるかの報告があった（xxvii）。 たとえば、イリノイ大学のLoretta Auvilらは， Bookwormというプログラムを使ってHathiTrustの 電子化された書籍の全文やメタデータを解析して， 年とともに動詞の不規則活用（burnt）が規則活用 (burned）に置き換えられていく様子などを示した。

\section{（3）DPLAその他の家族史資源}

移民と奴隷の国，米国では，国立公文書館やその 他のアーカイブを利用する目的の大部分が自分の ルーツを調べる家系調查である。現在利用できる ツールにはLouisiana Genealogy, Internet Archive Genealogy，The USGenWeb Projectなどがある。こ れらは住民台帳，教会信者台帳，奴隷台帳，センサス， 埋葬記録，死亡広告，興信録などを電子化したもの である。今後D PLAがこれらのプロジェクトと協力で きる可能性がある (xxvi)。

\section{4.まとめ}

インディアナポリスといっても，ほとんどの人は 簡単にイメージできないかもしれない。自動車レー スの「インディ 500」はこの近郊で行われる。

DPLAfesの開会式は，市の中心にあるインディアナ ポリス中央図書館で，その後大学図書館などいくつ かの会場に分散して分科会が開かれた（図5）。

前述したように，この会議は発表の場というより は議論の場であって，関係者がDPLAの課題や今後の 進め方について熱く発言していた。したがって，な かなか外部の人間にはついていきにくいところがあ る。日本でこのようなプロジェクトができるかとい うと簡単ではない気がする。図書館が協力して進め ているプロジェクトとしては，大学図書館による機 関リポジトリ連合が成功例の1つである。ただし，こ

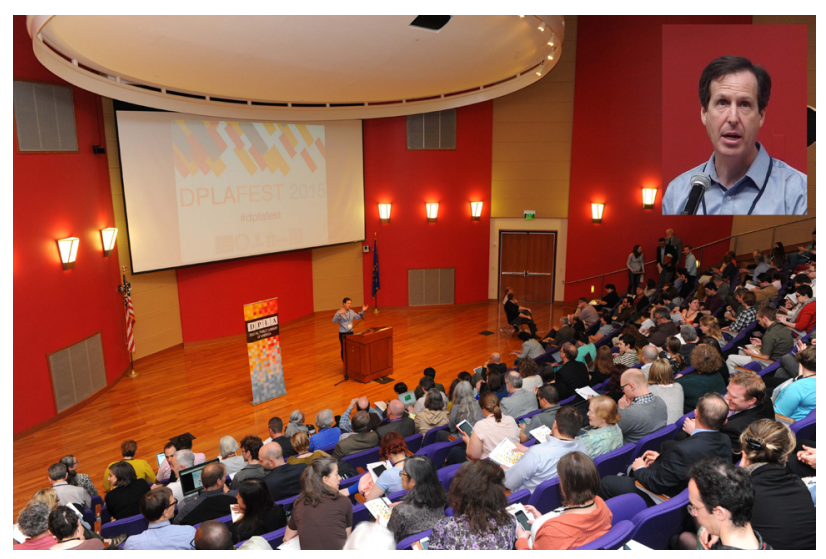

図5 インディアナポリス中央図書館における会議の様子と 事務局長のDan Cohen氏 
れも国立情報学研究所（NII）の強いリーダーシップ があってのことであろう。ハッカーのプロジェクト としてはCode4Lib JAPANがあるが，彼らもDPLAや Europeanaのような活躍の場を十分与えられていない 気がする。日本におけるデジタル・アーカイブの発 展モデルについてはこれから議論が必要である。

Europeana屯そうであるが，DPLAも活用を語る
フェーズに入ってきた。Wikipediaとの連携は非常に 期待がもてると感じた。

また米国でのアーカイブ活動はフェア・ユースで 厚く守られているということを実感した。わが国で はTPPによる著作権保護期間延長が語られる中，その ような安全網もなく，先の見えない思いである。

(東京大学大学総合教育研究センター 時実象一)

\section{本文の注}

注1） DPLAfest. 2015. http://dp.la/info/get-involved/dplafest/april-2015/, (accessed 2015-05-12).

注2) DPLA. http://dp.la/, (accessed 2015-05-12).

注3) DPLA Platform Overview. https://docs.google.com/document/d/1Pfl_q_LSLgplyzA7Gk2DmdZb2zqJR GrYQESVxhKwkLY/edit?pli=1, (accessed 2015-05-12).

注4) DPLA. Hubs. http://dp.la/info/hubs/, (accessed 2015-05-06).

注5) The Digital Public Library of America Announces New Partnerships, Initiatives, and Milestones at DPLAfest 2015. http://dp.la/info/2015/04/18/the-digital-public-library-of-america-announces-newpartnerships-initiatives-and-milestones-at-dplafest-2015/, (accessed 2015-05-06).

注6）大学図書館書籍アーカイブHathiTrust. http://dx.doi.org/10.1241/johokanri.57.548, (accessed 2015-0512).

注7) The Statement of Best Practices in Fair Use of Collections Containing Orphan Works for Libraries, Archives, and Other Memory Institutions http://cmsimpact.org/orphanworks, (accessed 2015-05-06).

注8) DPLA Hubs Showcase. https://drive.google.com/a/jst.go.jp/folderview?id=0BzpQeSFqkiZKfnR4ZGZLd WIwaFZteXI4dk1kZ21LY1dJR3I2UGFHLXphTEIhM3ZnRlpfMXM\&usp=sharing\#, (accessed 2015-05-06).

\section{参考文献}

1) 時実象一.デジタル・アーカイブの最前線. 講談社, 2015, p. 163-167.

2）時実象一. 米国デジタル公共図書館. 図書館雑誌. 2013, vol. 107, no. 2, p. 118-120.

3) Rudersdorf, Amy; Gore, Emily. Becoming a Hub. https://drive.google.com/a/jst.go.jp/folderview?id=0B zpQeSFqkiZKfnR4ZGZLdWIwaFZteXI4dk1kZ21LY1dJR3I2UGFHLXphTEIhM3ZnRIpfMXM\&usp=sharing\#, (accessed 2015-05-06).

4) Abbott, Franky; Cohen, Dan. Using Large Digital Collections in Education: Meeting the Needs of Teachers and Students. Digital Public Library of America. 2015/4/9. http://dp.la/info/wp-content/uploads/2015/04/ Using-Large-Collections-in-Education-DPLA-paper-4-9-15-2.pdf, (accessed 2015-05-06). 